\title{
School Engagement Among Adolescents from Low Income Family in Kuala Lumpur
}

Salina Nen, Fauziah Ibrahim, Mohd. Nasir Selamat, Nasrudin Subhi, Norulhuda Sarnon, Azianura Hani Ahsari, Shahrul Nazmi Sanusi dan Zaizul Abd. Rahman

To Link this Article: http://dx.doi.org/10.6007/IJARBSS/v11-i6/10224

DOI:10.6007/IJARBSS/v11-i6/10224

Received: 15 April 2021, Revised: 18 May 2021, Accepted: 30 May 2021

Published Online: 16 June 2021

In-Text Citation: (Nen et al., 2021)

To Cite this Article: Nen, S., Ibrahim, F., Selamat, M. N., Subhi, N., Sarnon, N., Ahsari, A. H., \& Rahman, S. N. S. dan Z. A. (2021). School Engagement Among Adolescents from Low Income Family in Kuala Lumpur. International Journal of Academic Research in Business and Social Sciences, 11(6), 936-945.

Copyright: (C) 2021 The Author(s)

Published by Human Resource Management Academic Research Society (www.hrmars.com) This article is published under the Creative Commons Attribution (CC BY 4.0) license. Anyone may reproduce, distribute, translate and create derivative works of this article (for both commercial and non-commercial purposes), subject to full attribution to the original publication and authors. The full terms of this license may be seen at: http://creativecommons.org/licences/by/4.0/legalcode

Vol. 11, No. 6, 2021, Pg. 936- 945

Full Terms \& Conditions of access and use can be found at http://hrmars.com/index.php/pages/detail/publication-ethics 


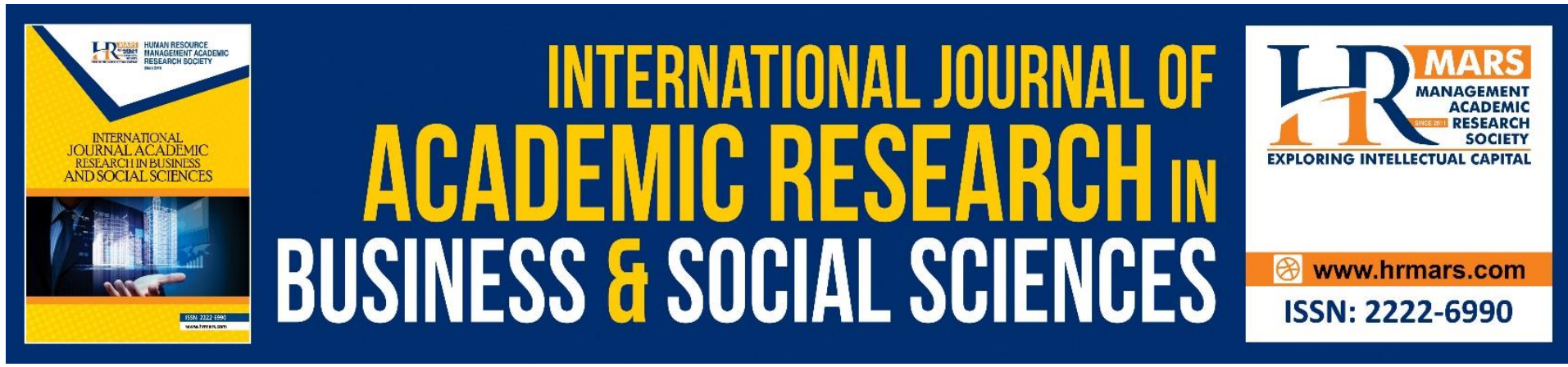

\title{
School Engagement Among Adolescents from Low Income Family in Kuala Lumpur
}

\author{
Salina Nen, Fauziah Ibrahim, Mohd. Nasir Selamat, Nasrudin \\ Subhi, Norulhuda Sarnon, Azianura Hani Ahsari, Shahrul \\ Nazmi Sanusi dan Zaizul Abd. Rahman \\ Pusat Pemerkasaan Remaja (PERKASA), Faculty of Social Science and Humanities, \\ Universiti Kebangsaan Malaysia, 43600 Bangi Selangor \\ Email: ifauziah@ukm.edu.my
}

\begin{abstract}
School engagement influence children's success rates and prevent students from engaging into various social problems. Commitment to school may be influenced by many factors including family background, student-teacher relationship, school peers, and curriculum and co-curricular activities taught at school. The study's two objectives were (1) to measure the level of students' commitment; and (2) to measure the factors that influence students' commitment to the school. This study used quantitative research designs in which questionnaires were the primary tool for data collection. The respondents of this study consisted of 244 teenagers aged between 11-25 years old living in People's Housing (PPR) in Kuala Lumpur. The findings showed that the level of commitment to the school was moderate $(50.8 \%)$, followed by high levels (43\%) and low (6.1\%) respectively. Meanwhile, there were four (4) factors identified to affect school commitment, and there were family relationships $(23.3 \%)$, personal health $(7.1 \%)$, prosocial behavior $(2.3 \%)$ and sexual health $(2.3 \%)$. The combination of the four predictor factors has contributed as much as $34.9 \%$ of the variance in school commitment among adolescents living in PPR. The implications and recommendations of this study for risky adolescent interventions were also discussed.
\end{abstract}

Keywords: School Engagement, High Risk Adolescence, Adolescent Education, Urban Adolescence

\section{Introduction}

Malaysians are classified into three (3) categories based on their income levels: T20 (top 20\%), M40 (middle 40\%), and B40 (bottom 40\%). Individuals with a monthly income of RM13, 148 make up the T20 category, according to the Malaysian Department of Statistics. M40 has a monthly minimum income of RM6275, while B40 has a monthly minimum income of RM3900. B40, on the other hand, is more vulnerable to the negative effects of increasing living costs, especially those who live in cities. The B40 community is often linked to poverty, which can contribute to a variety of psychosocial issues such as mental illness, school dropouts, violence, and drug abuse. Since their limited sources of income affect their quality of living and access to better resources, family members in the B40 community are more vulnerable to different 
risks than those in the middle- and high-income classes. As a result, a country like Malaysia must pay particular attention to the B40 community for them to continue to benefit from national development facilities without the risk of missing out. Similarly, it is important to ensure that the B40 family's second generation will strengthen and upgrade their lives in order to experience a higher quality of life. One of the focused is ensuring that the younger generation continues to attend school because education is directly related to better jobs and income opportunities.

\section{Literature Review}

Many factors influence students' academic achievement, particularly among adolescents. Attendance to school is one of the factors that is said to have a major impact on school students' achievement, especially in secondary school (Tharshini \& Fauziah, 2020; Fredricks, 2015; Gosain, 2013; Okwakpam \& Okwakpam, 2012). Attendance to school is one of the indicators of students' engagement to the learning process they are undergoing, and whether students will follow all aspects of the school process, including following the subjects taught, completing homework, participation in co-curricular activities, maintaining good relationships with teachers and peers, and active involvement in school-related activities (Fredrick, 2015). Demir and Karabeyoglu (2016), for example, investigated the impact of individual, family, and school factors on school truancy among Burdur primary school students. A total of 581 students in grades 9 to 11 participated in the study, with 44 percent of males and 56 percent of females. The data for the study was gathered using instruments with five domains: personal information, school truancy factors, school engagement, school environment standard, and parental control. According to the findings of their research, students' personal engagement to school became a significant predictor of truancy, followed by parental control. The school atmosphere and truancy activities are moderated by students' dedication to school.

Then there was a study by Oelsner, Lippold, and Greenberg (2011) that looked at the impact of factors like gender, substance abuse, antisocial peers, deviant behavior, and academic achievement on adolescent developmental processes. A total of 2902 high school students took part in the study. According to the findings of their research, adolescent commitment to school declined as they grew older. Male adolescents, on the other hand, were found to have lower connection levels than female adolescents. School density is said to be linked to deviant behavior, antisocial peers, and low academic achievement. Low academic achievement has been linked to an increased risk of substance abuse and school attachment. Person, family, and social environmental influences on substance abuse behaviour in adolescents were investigated in a local study by Rozmi et al (2017). A total of 480 adolescent respondents between the ages of 13 and 17 took part in this survey. According to Rozmi's study, risky conditions in schools account for 45.5 percent of the variation in adolescent substance abuse. Okwakpam and Okwakpam (2012) explored the influence of student characteristics and family history in the causes and truancy among adolescents. Purposive sampling was used to recruit 105 school teachers for the research, which took place in Nigeria. A standardised questionnaire was used to conduct the research. According to the findings of their report, there were substantial variations in family history and student variables. Students with low self-esteem, for example, were more likely to miss school, according to their research. Furthermore, poor health causes students to miss school and put less effort into their studies. Students with unstable emotions were found to be absent from classes. However, poor 
academic achievement was found to be unrelated to truancy conduct in this study. In the meantime, factors such as financial difficulties, the death of a parent, a lack of parental control, single parents, parental conflict, parental divorce, and parents' lack of support for education all lead to school truancy. The same study discovered that school influenced truancy activity to some degree. Irrelevant curriculum, inadequate classroom setting, poor teaching abilities, lack of interest in the subjects taught, lack of communication between school-parent, rigid administrative policies, and lack of activity in school are all factors that lead to truancy conduct among high school students, according to all respondents $(100 \%)$. Community factors also affect school truancy, according to the same survey, with 97 percent of respondents agreeing with this factor. Lack of community support for schools, negative peer impact, gangsterism activities in the community/school, community crisis, lack of quality transportation services in the community, and high rates of illegal activity and violence in the community are only a few of them.

Balkin, Arslan, and Duru (2016) looked at the direct and indirect links between truancy behavior, personal factors (self-perception of academics, attitudes toward teachers, school, goals and motivation/discipline), and family factors (parental education level, income) and academic achievement in a study. This research included a total of 123 high school students. The study discovered that school truancy had a strong negative relationship with school participation. Truancy was found to be negatively associated with academic expectations, attitudes toward school and teachers, goals, motivation, and academic performance in this study. The study's results also indicate that truancy varies depending on the parents' level of education and income. Student's truancy is strongly influenced by family and personal influences. Truancy in the past was also found to be a major predictor of academic achievement in the past, based on SEM analysis. The analysis also reveals that students' previous truancy activity and academic achievement will predict their current school truancy. From these studies, it can be inferred that various internal and external influences affect students' motivation or dedication to school. As a result, the aim of this research was to assess the level and factors that influence school engagement among adolescents from low income family family in Kuala Lumpur.

\section{Methodology}

\section{Research Objective}

The primary goals of this study are to (1) assess school commitment among B40 students in PPR, and (2) identify the factors that influence school commitment among B40 students.

\section{Research Design}

This research is conducted as a quantitative cross-sectional survey. Descriptive tests and stepwise multiple regression analysis were used to evaluate the study results. The 'Statistical Package for the Social Science for Windows (SPPS for Windows) was used to analyse the data. In this study, the following instruments were used:

1. The Commitment to School Scale includes six questions about B40 adolescents' commitment to school. The scale used in this analysis has a high reliability value of 0.734 .

2. The Family Relationship Scale includes five questions about B40 adolescents' family relationships. The scale has a reliability value of 0.807 . 
3. The Support for Prosocial Activity in Adolescents Scale includes four questions about prosocial behaviour support in B40 adolescents. The scale has a reliability score of 0.757.

4. The Personal Health Scale asks B40 adolescents six questions about their personal health. The scale has a reliability value of 0.736 .

5. The Sexual Health Scale asks B40 teenagers six questions about their sexual health. The scale has a reliability score of 0.767 .

Fauziah et al. (2017) developed all these questionnaires using Likert four-point scales, with the options arranged in order of appropriateness, namely (1) strongly disagree, (2) disagree, (3) agree, and (4) strongly agree.

\section{Descriptive Analysis}

The term "descriptive analysis" refers to a statistical technique for describing the characteristics of variables (Chua, 2012). The first study's objective was to measure the level of scholl engagement among B40 adolescents living in public housing areas, and descriptive analysis such as frequency, mean, percentage, and standard deviation were used in this study to achieve that purpose.

\section{Multiple Regression Analysis}

Changes in two or more factors (independent variables) that lead to changes in a dependent variable are identified using multiple regression (Chua, 2012). The objective of the second study, which is to identify factors that influence commitment to school among B40 adolescents living in residential areas in Malaysia, is measured using multiple regression analysis using the stepwise method. The stepwise approach has an advantage over other multiple regressions, according to Diekhoff (1992) since it only includes important predictor variables in the regression. The second benefit is that stepwise multiple regression will prevent the multicollinearity issue that occurs when predictor variables have large correlations. This association is irrelevant, and it reduces the accuracy of the study (Diekhoff, 1992). Since these problematic variables would not be included in the regression, this problem can be solved using stepwise multiple regression analysis.

\section{Population and Research Sample}

The sample population in this study is a group of B40 adolescents who live in people's housing areas in the Klang Valley. The People's Housing Project (PPR) is a housing project for lowincome family (Kuala Lumpur City Hall, 2005). A total of 244 adolescents aged 11 to 25 years were included in the study's sample. A total of 244 B40 adolescents were chosen using random sampling, as shown in Table 1 below:

Table 1: Location and Number of Research Sample

\begin{tabular}{clc}
\hline No & Research Location & Number of Sample \\
\hline 1 & PPR, Desa Rejang & 80 \\
2 & PPR, Pantai Ria & 80 \\
3 & PPR Seri Pantai & 84 \\
\hline & Total & $\mathbf{2 4 4}$ \\
\hline
\end{tabular}




\section{Survey Collection Process}

The researcher was assisted by a research assistant to carry out the survey and data collection process. The researchers provided a short overview and briefing on the data collection methods to the research assistants involved. The questionnaires were distributed in stages according to selected locations. Since all respondents can read and write, the questionnaire was filled out by them and monitored by research team so that they could ask if there were any questions they did not understand.

\section{Results and Discussion}

\section{Respondents' Profile}

In conclusion, based on the backgrounds of all B40 adolescents participating in this study, it was discovered that the majority of those involved in this study are in the middle age group of adolescents, ranging from 16 to 20 years old (57.4\%). Most of the respondents $(88.9 \%)$ are Malays with a secondary education standard of SRP/PMR and SPM (75.8\%) and are still in school (76.6\%). SRP/SPM is the highest level of education for the respondents' parents, namely the mother (59\%) and father (56.2\%) respectively. Most of the respondents' mothers (52.9\%) were stay-at-home moms, while their fathers worked full-time or part-time (65.6\%). According to the aspect of parental marital status, the majority of B40 adolescents in this study admitted that both their parents still live together, and most adolescents living in PPR also reported to have less than five (5) siblings (79.9\%). Most of the respondents (97.5\%), did not have a family history of substance use. Based on knowledge about the nature of the PERKASA programme, the study discovered that 58.2 percent of them are unaware of the program's existence, which is introduced in their housing, and only 26.6 percent of those who have participated in PERKASA, UKM programmes are aware of its existence. The study also discovered that most of respondents access social media in their own homes (67.6\%) and in cyber cafes (32.4\%), and that English learning opportunities are mostly provided by teachers in schools (84.4\%).

\section{School Engagement}

The study found that overall respondents living in PPR had a moderate (50.8\%) to high level (43\%) of engagement to school. Just 6.1 percent of the participants in this study demonstrated a low degree of engagement to the school, which needed to be improved.

Table 2: Level of Commitment Towards School $(n=244)$

\begin{tabular}{|c|c|c|c|}
\hline Level & $\mathbf{N = 2 4 4}$ & Percentage (\%) & Min \\
\hline Low & 15 & 6.1 & \multirow{2}{*}{3.03} \\
\hline Moderate & 124 & 50.8 & \\
\hline High & 105 & 43.0 & \\
\hline TOTAL & $\mathbf{2 4 4}$ & $\mathbf{1 0 0}$ & \\
\hline
\end{tabular}

As per Table 3, most respondents living in PPR expressed a strong desire to attend school (86.5 percent - item 1), had positive relationships with their teachers (87.3 - item 2), and reported having good academic achievement (82.8 percent -item3). Most respondents admitted to enjoying co-curricular activities in school ( 75 percent - item 4) and believed that enjoyable learning was one of the factors that encouraged them to go to school (81.5 percent -item 5). Even though the respondents' overall dedication to the school was high, the study revealed that $45.9 \%$ (item 6 ) of the respondents confessed to skipping school. 
Table 3: School Commitment Scale Percentage and Items

\begin{tabular}{|c|c|c|c|c|c|}
\hline No & Item & 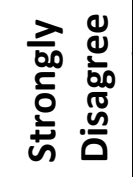 & 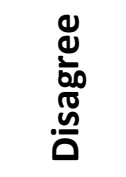 & 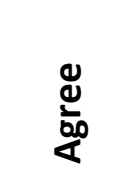 & 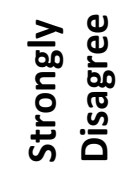 \\
\hline & \multicolumn{5}{|l|}{ Commitment to School } \\
\hline & \multicolumn{5}{|c|}{ Percentage (\%)/ Number } \\
\hline 1. & Going to school is something I enjoy doing. & $\begin{array}{c}12 \\
(4.9) \\
\end{array}$ & $\begin{array}{c}21 \\
(8.6) \\
\end{array}$ & $\begin{array}{c}99 \\
(40.6) \\
\end{array}$ & $\begin{array}{c}112 \\
(45.9) \\
\end{array}$ \\
\hline 2. & $\begin{array}{l}\text { My relationship with the school's teachers is } \\
\text { good. }\end{array}$ & $\begin{array}{c}12 \\
(4.9)\end{array}$ & $\begin{array}{c}19 \\
(7.8)\end{array}$ & $\begin{array}{c}95 \\
(38.9)\end{array}$ & $\begin{array}{c}118 \\
(48.4)\end{array}$ \\
\hline 3. & $\begin{array}{l}\text { My academic achievement in school was } \\
\text { good }\end{array}$ & $\begin{array}{c}12 \\
(4.9)\end{array}$ & $\begin{array}{c}30 \\
(12.3)\end{array}$ & $\begin{array}{c}129 \\
(52.9)\end{array}$ & $\begin{array}{c}73 \\
(29.9)\end{array}$ \\
\hline 4. & $\begin{array}{l}\text { I enjoy participating in extracurricular } \\
\text { activities at school. }\end{array}$ & $\begin{array}{c}17 \\
(7.0)\end{array}$ & $\begin{array}{c}44 \\
(18.0)\end{array}$ & $\begin{array}{c}90 \\
(36.9)\end{array}$ & $\begin{array}{c}93 \\
(38.1)\end{array}$ \\
\hline 5. & $\begin{array}{l}\text { I enjoy going to school because learning is } \\
\text { fun. }\end{array}$ & $\begin{array}{c}9 \\
(3.7) \\
\end{array}$ & $\begin{array}{c}36 \\
(14.8) \\
\end{array}$ & $\begin{array}{c}103 \\
(42.2)\end{array}$ & $\begin{array}{c}96 \\
(39.3) \\
\end{array}$ \\
\hline 6. & I used to skip school. & $\begin{array}{c}77 \\
(31.6)\end{array}$ & $\begin{array}{c}55 \\
(22.5)\end{array}$ & $\begin{array}{c}79 \\
(32.4)\end{array}$ & $\begin{array}{c}33 \\
(13.5)\end{array}$ \\
\hline
\end{tabular}

\section{Factors affecting school engagement}

The study found that four (4) factors influencing engagement to school among respondents in PPR were family relationships, personal health, prosocial behaviour, and sexual health, based on stepwise multiple regression analysis performed with a study sample. According to findings, family relationships $[F(1,225)=67,836, p .05]$ accounted for as much as 23.2 percent of the variance ( $R 2=.232$ ) in school engagement among PPR respondents. According to this report, the family relationship factor $(\beta=.481, p .05)$ is the most important factor affecting school engagement among PPR respondents. Whereas family relationships $(\beta=.362, p .05)$ and personal wellbeing $(\beta=.292, p .05)$ combined accounted for 7.1 percent of the change in school engagement. Prosocial behavioural factors and personal wellbeing, on the other hand, accounted for 2.3 percent and 1.2 percent of the difference in school engagement, respectively. The combination of these four predictor factors accounted for 34.9 percent of the variance in school commitment among PPR respondents.

Table 4: The Key Factors Affecting Commitment to B40 Adolescents in PPR Based on Regression Test Results ( $n=244)$

\begin{tabular}{lrrrrr}
\hline Variabel & Beta & $\mathbf{R}$ & $\mathbf{R}^{\mathbf{2}}$ & $\mathbf{F}$ & Sig \\
\hline Family Relationship & .481 & .481 & .232 & 67.836 & .000 \\
Personal Health & .292 & .550 & .303 & 48.637 & .000 \\
Prosocial Behavior & .176 & .571 & .326 & 35.884 & .000 \\
Sexual Health & -.154 & .591 & .349 & 29.720 & .000 \\
& & & & & \\
\hline
\end{tabular}

Dependent Variable: School engagement

The results of this study are in line with Okwakpam and Okwakpam's previous research (2012). Financial difficulties, death, lack of parental control, parental conflict, parental 
divorce, and a lack of compassion for educational values all have an effect on students' engagement and motivation, according to the researchers. Balkin, Arslan, and Duru (2016) discovered that family factors significantly predicted student truancy. Mental health studies have long shown the importance of intervention and prevention in schools for students who are at risk of developing mental health disorders or who are exhibiting signs of mental illness (Bradshaw et al., 2008). Furthermore, health issues such as frequent illness will cause students to miss school (Okwakpam and Okwakpam, 2012). Md Fadli (2002) defines health as a state or condition in which an individual is in optimal physical, mental, and social well-being, rather than simply being free of disease.

Schools should provide an atmosphere that encourages prosocial activity. Self-control, problem-solving skills, and social skills are examples of prosocial activities. Prosocial behaviour has been shown to be a major indicator of academic achievement in previous research (Heydenberk et al., 2006). Aggressive activities, such as bullying, have a negative impact on students' academic performance and psychosocial well-being (Horne et al., 2007). The nature of students' relationships with their classmates is influenced by their social competence (Fraser, et al., 2005). Peer acceptance and positive emotions are increased by interventions that reinforce social skills and prosocial behaviours. They can, however, discourage students from learning while avoiding delinquent habits such as substance use and other mental health issues.

Another factor that influenced respondents' engagement to school was their sexual health. Positive sexual health behavior should be based on good sexual knowledge. Accurate sexual information can aid adolescents in understanding sexual growth, as well as preserving, controlling, and influencing their emotions and psychological well-being (Low, 2009; Nasrudin, Fauziah, Norulhuda, Salina et al., 2020). Adolescence is also a period when it can be difficult to differentiate between good and immoral acts. This is regarded as a natural and essential part of the development of adolescent moral values (Coon \& Mitterer, 2012). However, in Malaysian culture, conversations about sexuality and reproductive health problems are still considered taboo. This is also an uncomfortable topic to bring up for more open discussion among adolescents who are considered too young to discuss sexual matters. Adolescents who have had a good sexual experience, on the other hand, have good sexual behaviours. Adolescents who have had poor sexual experiences, on the other hand, have unrealistic perceptions of sexual encounters, which leads to risky sexual conduct (Aini \& Ramadhy, 2013; Norulhuda, Mohamad, Fauziah et al., 2012; Alavi, Nen, Fauziah et al., 2012). Haglund and Fehring's (2010) findings show that early exposure to sexual information is important for adolescents because those who receive formal sexual education are 17 percent less likely to engage in sexual activity than those who do not.

The following are recommendations based on the study's findings to help increase the participation of students from low-income and at-risk families in school:

- The school improves its current facilities so that students can take advantage of them to their full potential. They are, for example, improving psychological and counselling services in schools to assist students who are dealing with personal and social issues at home or at school. Furthermore, involving departments such as the police is crucial in fostering a sense of security and preventing the spread of deviant behaviour in schools. 
- Collaboration between parents and school administration should be improved. More regular meetings with the school and parents to identify current needs and problems that can impact a student's academic success. This allows issues to be addressed more quickly and efficiently.

- Expand the school's social network to include more community organisations that can contribute ideas for more active social events, projects, visits, and exposures for students. The learning process is more exciting and meaningful when there is a social network between the school and other stakeholders.

\section{Conclusion}

Family relationships, personal wellbeing, prosocial behaviour, and sexual health among adolescents living in PPR must be strengthened by programmes organised by stakeholders to enhance and increase school engagement among adolescents living in PPR. More school programmes are needed to help at-risk students strengthen their family relationships, personal wellbeing, prosocial attitudes, and sexual health. The results of this report, for example, can be used by school counsellors to influence programme approaches that focus on the important factors discussed above. The programme that will be introduced must be flexible enough to meet the needs of students in this group while still being cost-effective enough for students to participate. Furthermore, an intervention that incorporates the roles of schools, parents/families, and the community in the creation of a conducive learning and schooling atmosphere for students is needed. These variables may be used to resolve the signs of truancy or school dropout, increasing student interest and dedication to the school.

\section{Acknowledgment}

This study has received support and funding from the Prime Minister's Department through the SK-2016-16 research code Research Grant. Acknowledgments are also extended to the Youth Empowerment Center (PERKASA) Faculty of Social Sciences and Humanities, UKM and all those who have been involved in the success of this study.

\section{References}

Aini, K., \& Ramadhy, A. S (2013). Perilaku seksual remaja masa lalu, masa kini dan masa depan serta dampaknya terhadap derajat kesehatan reproduksi di Indonesia. Naskah Publikasi.

Khadijah, A., Salina, N., Fauziah, I., Noremy, M. A., Mohamad, S. M., Nordin, M. N. (2012). Hamil luar nikah dalam kalangan remaja. e-Bangi Journal of Social Sciences and Humanities, 7(1), 131-140.

Balkis, M., Arslan, G., \& Duru, E. (2016). The School Absenteeism among High School Students: Contributing Factors. Educational Sciences: Theory \& Practice, 16 (6), 1819-1831.

Bradshaw, C. P., Koth, C. W., Thornton, L. A., \& Leaf, P. J. (2008). Altering school climate through school-wide positive behavioral interventions and supports: Findings from a group randomized effectiveness trial. Prevention Science, Vol. 10 (2), 110-115.

Coon, D., \& Mitterer, J. O. (2012). Introduction to psychology: Active learning through modules. Ed. Ke-12. Belmont, CA: Wadworth Cengage Learning.

Demir, K., \& Akman Karabeyonglu, Y. (2016). Factors associated with absenteeism in high schools. Eurasian Journal of Educational Research, Issue 62, 37-56.

Fraser, M. W., Galinsky, M. J., Smokowski, P. R., Day, S. H., Day, M. A., Terzian, R. A., \& Guo, S. (2005). Social informationprocessing skills training to promote social competence and 
prevent aggressive behavior in third grade. Journal of Consulting and Clinical Psychology 73(6): 1045-1055.

Fredricks, J. A. (2015). Academic engagement. In J. Wright (Ed.), The international encyclopedia of social and behavioral sciences (2nd ed., Vol. 2, pp. 31-36). Oxford: Elsevier.

Gosain, N. C. (2013). A Study of the factors leading to truancy among adolescent students in district Faridabad. Journal of Research \& Method in Education, 1 (6), 13-19.

Horne, A. M., Stoddard, J. L., \& Bell, C. D. (2007). Group approaches to reducing aggression and bullying in school. Group Dynamics: Theory, Research and Practice 11(4), 262-271.

Heydenberk, R.A., Heydenberk, W.R., \& Tzenova, V. (2006). Conflict resolution and bully prevention: Skills for school success. Conflict Resolution Quarterly 24(1), 55-69.

Low, W. Y. (2009). Malaysian youth sexuality: Issues and challenges. J. Univ Malaya Med Centre 12 (1), 3-14.

Malhotra, N. K., Hall, J., Sham, M., \& Crsip, M. (1996). Marketing Research: Applied Orientation (1st Edition). Sydney: Prentice Hall

Norulhuda, S., Mohamad, S. M., Fauziah, I., Khadijah, A., K., Salina, N., Suzana, M. H., Zaizul, A. R., \& Wan Azreena, J. (2012). Hamil luar nikah: Memahami remaja sebagai asas intervensi Keluarga. E-Bangi, Journal of Social Science \& Humanities, 7(1), 121-130.

Oelsner, J., Lippold, M. A., \&Greenberg, M. T. (2011). Factors influencing the development of school bonding among middle school students. Journal Early Adolescent, 31(3), 463487. doi:10.1177/0272431610366244.

Okwakpam, I. N., \& Okwakpam, I. O. (2012). Causes and levels of truancy among secondary school students: A case study of Rivers State, Nigeria. Problems of Education In The 21th Century, 45, 51-62.

Rozmi, I., Azri, N. A., Fauziah, I., \& Salina, N. (2017). The influence of individual, familial and social environment factors towards substance abuse behavior among adolescents. Akademika, 87(1), 7-16.

Nasrudin, S., Fauziah, I., Norulhuda, S., Salina, Nen., Azianura, H. S., A. H., Nasir, M. S., Zaizul, A. R. N., Nazmi, S., Daniella, M. (2020). Sexual health among youth at risk in Kuala Lumpur. International Journal of Psychosocial Rehabilitation, 24(4), 4310-4322.

Tharshini, N. K., \& Fauziah, I. (2020). Faktor-faktor berisiko yang menyumbang kepada tingkah laku devian: Satu kajian ulasan sistematik. Jurnal Perspektif, 12(1), 28-38. 